DOI https://doi.org/10.30525/978-9934-26-006-3-3

\title{
КОЛЛЕКЦИЯ ГОЛОСЕМЕННЫХ РЕЛИКТОВ В ДЕНДРОЛОГИЧЕСКОМ ПАРКЕ «АЛЕКСАНДРИЯ» НАН УКРАИНЫ
}

\begin{abstract}
Дойко Н. М.
кандидат биологических наук, старший научныий сотрудник, заведующая отделом обогащения дендрофлоры Государственный дендрологический парк «Александрия»

Национальной академии наук Украинь
\end{abstract}

Кривдюк Л. М.

ведущий инженер лаборатории семеноводства и первичного испытания интродуцированных растений Государственный дендрологический парк «Александрия»

Начиональной академии наук Украинь 2. Белая Церковь, Киевская область, Украина

Сохранение генофонда реликтовых видов является важной задачей фитосозологии. Существует ряд определений реликта, в частности, Е. Вульф (1941) рассматривает реликт как понятие историкогеографическое. Реликтовым видом в его трактовке является «остаток более или менее древней флоры, имеющий реликтовый ареал, занимаемый им с момента вхождения в состав означенной флоры» [1]. Проблема реликтовых растений в научной литературе поднимается уже более 100 лет, но до настоящего времени среди исследователей нет единого мнения о критериях реликтовости $[2,3,4,6]$.

Ботанические учреждения, имеющие огромные коллекции живых растений, относятся к основным центрам изучения, сохранения, размножения реликтовых растений. Показателем эффективности деятельности ботанических учреждений в отношении охраны реликтовых видов являются их коллекции [5].

На территории Государственного дендропарка «Александрия» НАН Украины, являющегося приемником одноименного приусадебного парка графов Браницких, за 230 летний период существования собрана большая коллекция древесных растений, в том числе и разного охранного статуса. 
Целью нашей работы была инвентаризация реликтовых древесных растений дендропарка, анализ таксономического состава. оценка состояния.

Значительная часть реликтовых растений произрастает в ландшафтах парка с начала его основания и достигла возраста около 200 лет, более молодые растения произрастают на коллекционных участках «Фрутицетум» (создан в 60-х годах $\mathrm{XX}$ века) и «Кониферетум» (заложен в 2004 г.) (таблица 1).

Таблица 1

\section{Реликтовые растения дендрологического парка «Александрия» НАН Украины}

\begin{tabular}{|c|c|c|c|c|c|c|}
\hline № & Название вида & 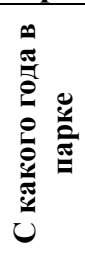 & $\frac{\mathscr{0}}{\stackrel{0}{0}}$ & 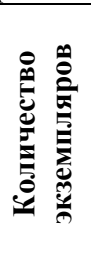 & 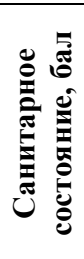 & $\begin{array}{l}\text { Приме- } \\
\text { чание }\end{array}$ \\
\hline 1 & 2 & 3 & 4 & 5 & 6 & 7 \\
\hline \multicolumn{7}{|c|}{ Класс Ginkgopsida } \\
\hline 1. & Ginkgo biloba $\mathrm{L}$. & 1960 & К, П & 7 & III & $\begin{array}{c}\text { палеозой } \\
\text { ская эра }\end{array}$ \\
\hline \multicolumn{7}{|c|}{ Класc Pinopsida } \\
\hline \multicolumn{7}{|c|}{ Семейство Cupressaceae } \\
\hline 2. & $\begin{array}{l}\text { Chamaecyparis } \\
\text { lawsoniana Parl. }\end{array}$ & 1992 & $\Pi$ & 10 & II & \multirow{4}{*}{$\begin{array}{c}\text { меловой } \\
\text { период } \\
\text { мезозойс } \\
\text { кой эры }\end{array}$} \\
\hline 3. & Juniperus sabina L. & 1964 & $\Phi, \Pi$ & 200 & I & \\
\hline 4. & $\begin{array}{c}\text { Juniperus semiglobosa } \\
\text { Regel }\end{array}$ & 1961 & $\Phi$ & 3 & I & \\
\hline 5. & Juniperus virginiana $\mathrm{L}$. & 1880 & $\Phi, \Pi$ & 65 & I-III & \\
\hline 6. & $\begin{array}{c}\text { Microbiota decussata } \\
\text { Kom. }\end{array}$ & 1990 & K & 3 & II & $\begin{array}{c}\text { миоценов } \\
\text { ая эпоха } \\
\text { кайнозой } \\
\text { ской эры }\end{array}$ \\
\hline 7. & Thuja occidentalis L. & 1958 & $\Phi, К, \Pi$ & $>550$ & II-III & \multirow{2}{*}{$\begin{array}{c}\text { меловой } \\
\text { период } \\
\text { мезозойс } \\
\text { кой эры }\end{array}$} \\
\hline 8. & Thuja plicata D. Don. & 1959 & $\Pi$ & 7 & III & \\
\hline
\end{tabular}


Продовження таблиці 1

\begin{tabular}{|c|c|c|c|c|c|c|}
\hline 1 & 2 & 3 & 4 & 5 & 6 & 7 \\
\hline \multicolumn{7}{|c|}{ Семейство Pinaceae Lindl. } \\
\hline 9. & Abies alba Mill. & 1958 & $\Pi$ & 46 & III & \multirow{13}{*}{$\begin{array}{l}\text { плиоцено } \\
\text { вая эпоха } \\
\text { кайнозой } \\
\text { ской эры }\end{array}$} \\
\hline 10. & $\begin{array}{l}\text { Abies balsamea (L.) } \\
\text { Mill. }\end{array}$ & 1960 & $\mathrm{~K}$ & 3 & II-III & \\
\hline 11. & $\begin{array}{c}\text { Abies concolor (Gord.) } \\
\text { Hoopes }\end{array}$ & 1963 & $\Phi, \Pi$ & 42 & II-III & \\
\hline 12. & Abies koreana Wils. & 1990 & $\mathrm{~K}$ & 2 & II & \\
\hline 13. & $\begin{array}{l}\text { Abies procera } \text { Beiss. } \\
\text { 'Glauca' }\end{array}$ & 2004 & $\mathrm{~K}$ & 2 & II & \\
\hline 14. & Larix czekanowskii Szaf. & 1985 & $\Pi$ & 3 & III & \\
\hline 15. & Larix dahurica Turez. & 1985 & $\Pi$ & 4 & III & \\
\hline 16. & Larix decidua Mill. & 1850 & $\Phi, \Pi$ & 25 & II-II & \\
\hline 17. & $\begin{array}{c}\text { Larix gmelinii (Rupr.) } \\
\text { Rupr. }\end{array}$ & 1985 & $\Pi$ & 4 & III & \\
\hline 18. & $\begin{array}{l}\text { Larix kaempferi (Lamb.) } \\
\text { Carr. }\end{array}$ & 1958 & $\Pi$ & 2 & II-III & \\
\hline 19. & Larix $\mathrm{x}$ marschlinsii Coas. & 1976 & $\Pi$ & 4 & III & \\
\hline 20. & $\begin{array}{l}\text { Larix polonica } \text { Racib. ex } \\
\text { Szaf. }\end{array}$ & 1820 & $\Pi$ & 1 & II & \\
\hline 21. & Larix sibirica Ledeb. & 1860 & $\Pi$ & 100 & II-II & \\
\hline 22. & Picea abies (L.) Karst. & 1790 & $\Pi$ & 850 & II-IV & \multirow{15}{*}{$\begin{array}{c}\text { меловой } \\
\text { период } \\
\text { мезозойс } \\
\text { кой эры }\end{array}$} \\
\hline 23. & $\begin{array}{l}\text { Picea engelmanii } \\
\text { Engelm. }\end{array}$ & 2002 & $\mathrm{~K}$ & 1 & I & \\
\hline 24. & Picea breweriana Wats. & 2004 & $\mathrm{~K}$ & 2 & I & \\
\hline 25. & $\begin{array}{c}\text { Picea glauca } \text { (Moench) } \\
\text { Voss. }\end{array}$ & 1960 & $\Pi$ & 10 & II-III & \\
\hline 26. & Picea glehnii Mast. & 2002 & K & 1 & I & \\
\hline 27. & Picea montigena Mast. & 2004 & K & 1 & I & \\
\hline 28. & $\begin{array}{c}\text { Picea orientalis (L.) } \\
\text { Link. }\end{array}$ & 2002 & $\Phi$ & 1 & II & \\
\hline 29. & Picea pungens Engelm. & 1978 & $\Phi, \Pi$ & 13 & I-III & \\
\hline 30. & Picea rubens Sarg. & 2002 & $\Phi$ & 1 & III & \\
\hline 31. & Pinus aristata Engelm. & 2004 & K & 5 & II & \\
\hline 32. & Pinus armandii Franch. & 1995 & $\Pi$ & 3 & $\mathrm{I}$ & \\
\hline 33. & Pinus bungeana Zucc. & 2005 & K & 1 & II & \\
\hline 34. & Pinus cembra L. & 2003 & К, $\Phi, \Pi$ & 4 & I-II & \\
\hline 35. & $\begin{array}{c}\text { Pinus koraiensis Sieb. et } \\
\text { Zucc. }\end{array}$ & 1992 & $\Pi$ & 2 & II & \\
\hline 36. & Pinus nigra Arn. & 1820 & $\Pi$ & 36 & II-III & \\
\hline
\end{tabular}


Продовження таблиці 1

\begin{tabular}{|c|c|c|c|c|c|c|}
\hline 1 & 2 & 3 & 4 & 5 & 6 & 7 \\
\hline 37. & Pinus pallasiana D. Don & 1930 & $\Pi$ & 2 & II & \\
\hline 38. & Pinus ponderosa Dougl. & 2004 & $\mathrm{~K}$ & 1 & II & \\
\hline 39. & Pinus sibirica Du Tour & 1977 & К, П & 6 & II & \\
\hline 40. & Pinus strobus L. & 1796 & $\Pi$ & 41 & II-III & \\
\hline 41. & Pinus sylvestris L. & 1796 & $\Pi$ & 1200 & $\mathrm{I}-\mathrm{V}$ & \\
\hline 42. & $\begin{array}{c}\text { Pseudotsuga menziesii } \\
\text { (Mirb.) Franko }\end{array}$ & 1959 & $\Pi$ & 32 & II-III & $\begin{array}{c}\text { Раннемел } \\
\text { овой } \\
\text { период } \\
\text { мезозойс } \\
\text { кой эры }\end{array}$ \\
\hline \multicolumn{7}{|c|}{ Семейство Taxaceae Lindl. } \\
\hline 43. & Taxus baccata L. & 1960 & К, П & & II-III & \multirow{2}{*}{$\begin{array}{c}\text { позднетр } \\
\text { иасовый } \\
\text { период } \\
\text { мезозойс } \\
\text { кой эры }\end{array}$} \\
\hline 44. & $\begin{array}{l}\text { Taxus cuspidata Sieb. } \\
\text { et Zucc. ex Endl }\end{array}$ & 2013 & K & 1 & II & \\
\hline \multicolumn{7}{|c|}{ Семейство Taxodiaceae F.W.Neger } \\
\hline 45 . & $\begin{array}{c}\text { Metasequoia } \\
\text { glyptostroboides Hu et } \\
\text { Cheng }\end{array}$ & 2002 & К, П & 76 & II-II & $\begin{array}{c}\text { Плиоцен } \\
\text { овая } \\
\text { эпоха } \\
\text { кайнозой } \\
\text { ской эры }\end{array}$ \\
\hline 46. & $\begin{array}{c}\text { Cryptomeria japonica } \\
\text { D. Don. }\end{array}$ & 2003 & K & 11 & III & $\begin{array}{c}\text { Реликт } \\
\text { третичны } \\
\text { й период } \\
\text { кайнозой } \\
\text { ской эры }\end{array}$ \\
\hline
\end{tabular}

Примечание: $K$ - кониферетум, $\Phi-$ фрутицетум, $\Pi-$ - парк

Таким образом, на территории государственного дендрологического парка «Александрия» произрастает 46 видов реликтовых голосеменных растений, которые относятся к 2 классам: Ginkgopsida и Pinopsida, 4 семействам: Cupressaceae, Pinaceae, Taxaceae и Taxodiaceae, 13 родам. (табл. 1). Среди реликтовых голосеменных 7 видов имеют возраст 200 и более лет, 16 видов - средневозрастных, наибольше молодых, до 20 лет, которые произрастают главным образом на коллекционных участках (табл. 1).

По санитарному состоянию реликтовые растения распределены от здоровых (I категория жизненного состояния [7]) до сильно 
ослабленных (III категория), некоторые виды имеют усыхающие экземпляры.

Сравнение нашего инвентаризационного списка с архивными данными показало, что в разные периоды с насаждений парка исчез ряд видов реликтовых голосеменных растений. Chamaecyparis pisifera Endl. В парке произрастал с 1959 года, на 1997 год числилось 7 экземпляров в центральной и восточной частях парка. Juniperus chinensis L. (c 1959 года) - в западной части парка произрастало небольшой куртиной 5 экз., исчез после 2000 года. Juniperus communis L. c 1950 года в парке, произрастал в центральной и восточной частях парка. Juniperus exelsa Bieb. в парке с 1959 года, 1 экз. произрастал в западной части парка. Abies nordmanniana (Stev.) Spach, в центральной части парка произрастало 2 экз. с 1971 года. Исчезли из парковых ландшафтов 2 вида реликтовых сосен: Pinus banksiana Lamb., в парке с 1956 года, 2 экз.) и Pinus funebris Kom. в парке с 1980 года, в восточной части парка по кромке березовой рощи росло 8 экз. и другие виды.

В парке принята программа по восстановлению утраченных видов и лаборатория семеноводства и первичного испытания интродуцированных растений работает над приобретением, размножением данных видов растений. Сейчас на замену выпавших видов выращено и высажено на коллекционные участки Juniperus exelsa, Juniperus chinensis, Abies nordmanniana, Abies koreana

Таким образом, в парке и на коллекционных участках дендропарка «Александрия» произрастает 46 видов голосеменных растений, которые относятся к 2 классам, 4 семействам, 13 родам, различного возраста и различного санитарного состояния. Часть видов реликтовых голосеменных в разное время выпала из парковых ландшафтов. Дальнейшие работа с реликтовыми растениями предполагается в расширении их коллекции, эффективном размножении имеющихся видов и внедрении их в ландшафты парка, передача другим ботаническим учреждениям, восстановлении в ландшафтах парка утраченных видов реликтовых растений.

\section{Литература:}

1. Вульф Е.В. Понятие о реликте в ботанической географии // Материалы по истории флоры и растительности CCCP. M.-JL, 1941. Вып. 1. С. 2860.

2. Дидух Я.П. Эколого-ценотические особенности поведения некоторых реликтовых и редких видов в свете теории оттеснения реликтов // Бот. журн. 1988. Т. 73. № 12. С. 1686-1698. 
3. Колісніченко О.М., Гордзієвська Л.П., Іванова І.Ю. Голонасінні релікти Ботанічного саду ім. акад. О.В. Фоміна: довідник. К.: Видавничо-поліграфічний центр «Київський університет». 2014. 127 с.

4. Криштофович А.Н. Курс палеоботаніка. М.: Госгеонефтеиздат. 1934. $44 \mathrm{c}$.

5. Еленевский А.Г., Радыгина В.И. О понятии «реликт» и реликтомании в географии растений // Бюл. МОИП. Отд. биол. 2002. Т. 107. Вып. 3. С. 39-49.

6. Саксонов, С.В., Сенатор С.А. Понятие о реликте в ботанической географии (к 130-летию со дня рождения Е.В. Вульфа) // Известия Самарского научного центра РАН. 2014. Т. 16. № 5 (1). С. 643-650. 